\title{
INVESTIGATING TEACHERS' READINESS IN TEACHING INTEGRATED SOCIAL STUDIES: INDONESIAN CASES
}

\author{
Pupu Saeful Rahmat \\ Department of Economics Education, Postgraduate Studies, \\ Universitas Kuningan, Indonesia \\ Email: poesya59@gmail.com
}

\begin{abstract}
APA Citation: Rahmat, S. F. (2018). Investigating teachers' readiness in teaching integrated social studies: Indonesian cases. Indonesian Journal of Learning and Instruction, 1(1), 29-36.
\end{abstract}

Abstract: This research aims to find out: (1) how the readiness of teachers in Indonesia especially at SMP Negeri 3 Kuningan, West Java in teaching Integrated Social Studies in terms of the management of learning and (2) any constraints faced by Indonesian teachers in teaching Integrated Social Studies. The method used in this research is qualitative method. The results showed that the readiness of Indonesia teachers in teaching Integrated Social Studies in terms of learning management of $80,15 \%$ included in the ready category. Constraints faced by teachers in the field of teaching Integrated Social Studies, among others (1) Less united geography, economic, historical and sociological concepts in the minds of teachers (2) Limitations of supporting facilities of Integrated Social Studies learning at schools.

Keywords: teacher's readiness; teaching; integrated social studies.

\section{INTRODUCTION}

Education at schools is basically an educational process organized formally based on hierarchical and chronological structure, from kindergarten level to college level. In addition to referring to the implementation of applied in stages, the ongoing process of education at schools is very dependent on the existence of other subsystems consisting of students, management of school operations, the structure and timeschedule of teaching and learning activities, materials which are organized into a set of systems called curricula, educational activities, learning aids (textbooks, whiteboards, laboratories and audiovisuals), technology consisting of software (teaching strategies and tactics) as well as hardware (educational equipment), facilities buildings and supporting facilities and equipment, quality control sourced from target achievement goals, research for the development of educational activities and tuition fees in order to smooth the continuity of the education process.
In the history of education in Indonesia since the New Order era has implemented seven curriculum namely: curriculum 1968, curriculum 1984, curriculum 1994, curriculum 2004 or we call Competency-based Curriculum or familiar with KBK, Education Unit Level Curriculum or we call KTSP, and the last Curriculum 2013 (known as Kurtilas) issued by the government through Permendikbud number 54 of 2013 on Competency Standard of graduates, contents, Candidate number 23 on Graduate Competency Standard, and Permendikbud number 65 of 2013 on Standard Process, Permendikbud no. 66 of 2013 on the Appraisal Standards, Permendikbud No. 21 Year 2016 about content standard.

The implementation of the curriculum of integrated Social Studies was first introduced by the Curriculum Center around 2004, one of the innovations included in the KBK is the Integrated Natural Science (IPA) learning model and Integrated Social Studies (IPS) for Junior High School level. This integrated 


\section{Pupu Saeful Rahmat}

Investigating teachers' readiness in teaching integrated social studies: Indonesian cases

learning model requires, among others, that an Integrated Natural Sciences consisting of physics, biology and chemistry is taught by one teacher, as well as an Integrated Social Science consisting of geography, history, economics, sociology as well as one teacher only. This change certainly requires readiness of the teacher one of them in the management of learning from the planning stage of learning, the process of teaching and learning in the classroom until the stage of assessment (evaluation) ability of learners.

The integrated learning model raises the pros and cons in various circles, especially among teachers who have been accustomed to teach only one field. Geography teachers, for example, said they would find it difficult to teach economics, as well as economics teachers, saying they would find it difficult to teach geography. Nevertheless, not a few geography or economics teachers who regard the integrated learning model as a challenge and must be answered by increasing the knowledge of the teachers, either through formal education or through self-study. In connection with this implementation, especially in Junior High school, Integrated Social Studiesteachers are one of the key factors that play a key role, because they are the ones who will eventually implement the curriculum in the classroom, so that the achievement of the competency standards of the graduates. No matter what curriculum and educational system is available, without the support of qualified teachers, it will be in vain. Teachers will remain at the forefront of creating competent human resource quality as mandated in the Curriculum 2013 (or we call Kurtilas).

Based on KTSP and Kurtilas which requires that the field of Integrated Social Studies consisting of geography, history, economics and sociology is only taught by one teacher alone becomes a separate issue related to the educational background of teachers who teach Integrated Social Studiescomes from different disciplines and before Integrated Social Studiesapplied they only teach one field of study only in accordance with the background of the discipline it possesses. This change necessarily requires the readiness of teachers, one of which relates to the ability of teachers in the management of learning. Plus a variety of obstacles both concerning facilities that support teaching and learning activities in this case related to learning Integrated Social Studies Based on the problem identification, the problem in this research is limited to the readiness of the study subject teachers in teaching Integrated Social Studiesin terms of the management of learning.

Based on the description above, the formulation of the problem in this study are: (1) How is the readiness of teachers in SMP Negeri 3 Kuningan in teaching integrated Social Studies in terms of the management of learning? (2) What are the constraints faced by teachers in SMP Negeri 3 Kuningan in teaching Integrated Social Studies?

\section{METHOD}

The method used in this research is qualitative method. The research was aimed at 6 teachers of integrated Social Studies as research sample. The collection was done by interview, observation and spreading the questionnaire as much as the number of samples from the research. Questionnaire addressed to Social Studies teachers consists of 2 aspects namely the preparation of lesson plans and aspects of the implementation of teaching and learning interactions. For the questionnaire, the compilation of the lesson plan consists of 21 items and aspects of the implementation of teaching and learning interaction consists of 25 items.

The survey instrument contains a number of variables to test for significant differences based on the firms' characteristics and the owner managers' profile. Tables 2 and 3 provide summary statistics on the main variables of interest and information about Mauritian SMEs. The majority of the questionnaires were completed by the owner manager of the firm or his/her representatives, which in most of the cases were close family members that had been appointed as director. The presence of family members increases 
confidence in the completeness and reliability of the information provided.

\section{RESULTS AND DISCUSSION}

This study aims to find out how the readiness of teachers in the field of teaching integrated Social Studiesin SMP Negeri 3 Kuningan as a place of the research. Based on the questionnaire results, observations and interviews have been done on each respondent, the results obtained of the research as follows: The author distributed the questionnaire as many as the number of samples from the research that is to 6 teachers of Integrated Social Studies Questionnaire addressed to Social Studiesteachers consists of 2 aspects namely the preparation of lesson plans and aspects of the implementation of teaching and learning interactions. For the questionnaire, the compilation of the lesson plan consists of 21 items and aspects of the implementation of teaching and learning interaction consists of 25 items

\section{Preparation of learning plans}

The data processing of each questionnaire answered by the respondent has the following description: For the learning plan indicator, the teacher has very well arranged the lesson plan (100\%), the discipline in preparing the lesson plan, and the teacher uses the lesson plan in the class according to lesson plan has been compiled (100\%). In the indicator of the subject matter, the teacher has been very good at regular and systematic material presentation $(100 \%)$, both in carrying out past material repetition and relating it to new material $(85.15 \%)$, either in concluding the material at the end of the lesson (85\%) and very good at compiling the subject matter $(100 \%)$.

In teaching method indicator, teachers have used various methods and in accordance with the material characteristic (100\%), good enough in using the existing media facilities according to the method used (78\%) and good enough in applying teaching methods that make students active. In learning media indicator, teacher believes very well that learning media is very supportive of the achievement of competence to be mastered $(100 \%)$, teachers also have good enough in using instructional media in accordance with the applied method (68\%), but in using media that varies less (51\%), and less media planning $(52 \%)$, this is because of the lack of availability of Integrated Social

Studieslearning support media at schools.

For indicators of reading sources, teachers have delivered materials from other sources well (77\%), provided information about the literature to be used in learning $(87.75 \%)$ and designed the use of the student handbook very well $(89.75 \%)$. In the assessment indicator, the teacher assigns the students home duties and assesses (100\%), the teacher is also good at making the final assessment directly or indirectly (76\%), the teacher also assesses the students when the learning process takes place (68\%).

The indicator of time allocation given to Integrated Social Studies according to teachers are still insufficient (53\%), this is because the material taught very much.

\section{The implementation of teaching and learning interactions}

The data processing of each questionnaire answered by the respondent has the illustrated picture as follows: From learning skill indicators, the teacher did the material orientation well (78\%), apperception to the students very well $(85.75 \%)$ and motivated the students well (84.15\%). From the indicator of the presentation of the material, the teacher is very good in mastering the material of Social Studies (100\%), presents the material clearly to the students (100\%), and presents the material systematically $(89,75 \%)$. From the teaching method indicator, the teacher has used very well-planned methods $(96.75 \%)$, and taught using well-varied methods (78\%), but still lacks in linking methods with available media facilities (53\%).

From learning media indicator, teachers have used appropriate media of instructional material very well $(85,75 \%)$, but still less in media usage / teaching aids and various media (51\%). For communicative 


\section{Pupu Saeful Rahmat}

Investigating teachers' readiness in teaching integrated social studies: Indonesian cases

discussion and interaction indicators, teachers communicate very well $(94.85 \%)$, and very good at interacting and involving students $(95,50 \%)$. For motivational indicators, teachers provide motivation to students while teaching and learning process takes place in the classroom well (78\%) and on indicators of organizing teacher activities have been very good at organizing learning activities (100\%).

In the indicator of interaction with students communicatively very well done by the teacher $(100 \%)$. For indicators of inferred learning, teachers have concluded learning materials well (79\%) and for teacher feedback indicators have been very good at giving feedback (100\%). For the learning appraisal indicator, the teacher has given the post test at the end of the lesson (78\%) with good category, and gives assessment during the learning process $(74.45 \%)$ but rarely prepretests lesson (45\%). In the indicator of the use of time, the teacher opened the lesson on time (100\%), presented the core material on time $(93.90 \%)$, but in the end of the teaching and learning process is still in enough category $(58.15 \%)$, this is due to Integrated Social Studiesmaterial which will be submitted quite a lot, but the allocation of available time is very less according to the teacher.

\section{Teachers' readiness}

The average readiness of teachers in teaching Integrated Social Studies in terms of preparation of lesson plans. The result of the research based on the questionnaire of the compilation of the lesson plan shows that the average of teacher preparedness in teaching Integrated Social Studies at SMP Negeri 3 Kuningan is 78,25\% included in good category. The results of the research based on questionnaire implementation of teaching and learning interaction shows that the average of teachers preparedness field in teaching Ingrated Social Studies at SMP Negeri 3 Kuningan $85.95 \%$ included in either category. Thus, the teachers of the field of teaching Integrated Social Studies at SMP Negeri 3 Kuningan has been able to describe the competence of learning according to Kurtilas and has been able to organize learning activities well and planned. Form of assessment according to Kurtilas also been applied by the teacher of cognitive, affective and psychomotor assessment and this is reflected in the implementation plan of learning made by an integrated Social Studies teacher at SMP Negeri 3 Kuningan. However, the obstacles in the preparation of lesson plans according to the teachers is in allocating time, due to the many Integrated Social Studies material, the difficulty in adjusting the method with the learning model considering the background of students who are not all the same.

Based on the results of interviews with teachers the difficulties they experienced in the implementation of teaching and learning interaction, especially when they have to deliver material that is not in accordance with educational background, as well as teachers who have the background of geography education should convey the subject of historical material. According to them the historical science base tends to be memorable and enrichment whereas geography tends to the technique and mastery of concepts. This, implicated in the implementation of learning that goes just to convey the contents of the book because the mastery of historical material has not been embedded in the minds of teachers as embedded the concept of geography. Similarly, as perceived by teachers who have an economic education background when it comes to conveying geography and history materials. With such circumstances the teachers expressed feel less maximal in delivering the material to the students because just simply deliver the contents of the book plus the response of students who are less enthusiastic in following Integrated Social Studies (interview on March 15, 2017).

The constraints in terms of facilities that support Integrated Social Studies learning revealed by the teachers are limited Integrated Social Studies learning media. They revealed that in their schools the availability of instructional media is very minimal, for example when the lesson of Integrated Social 
Studiesgoes on the basic competence of interpreting the map about the pattern and shape of the earth, as the relevant media used is the map or the atlas, but the media is very limited in number, classes that will use quite a lot. Therefore teachers rarely use instructional media while teaching. However, these obstacles are overcome by teachers by making policies such as for atlases required by students to have their own.

Another reason the teacher disclosed about this media was about materials that did not need to use the media, as when on Integrated Social Studiesmaterial historical or sociological subject matter, according to them this material is enough to be delivered only by lecture method or discussion. Through interview writers with teachers who teach Integrated Social Studies in SMP Negeri 3 Kuningan they convey the suggestion that the school and the education office can more often conduct training for Integrated Social Studies so that their lack of understanding of materials that are not basic education they can be overcome. (Interview Thursday, March $23^{\text {th }}$, 2017).

The constraints in terms of facilities that support Integrated Social Studies learning revealed by the teachers are limited Integrated Social Studies learning media. They revealed that in their schools the availability of instructional media is very minimal, for example when the lesson of Integrated Social Studies goes on the basic competence of interpreting the map about the pattern and shape of the earth, as the relevant media used is the map or the atlas, but the media is very limited in number, classes that will use quite a lot. Therefore teachers rarely use instructional media while teaching. However, these obstacles are overcome by teachers by making policies such as for atlases required by students to have their own.

Another reason the teacher disclosed about this media was about materials that did not need to use the media, as when on Integrated Social Studies material historical or sociological subject matter, according to them this material is enough to be delivered only by lecture method or discussion. Through interview writers with teachers who teach Integrated Social Studiesin SMP Negeri 3 Kuningan they convey the suggestion that the school and the education office can more often conduct training for Integrated Social Studies so that their lack of understanding of materials that are not basic education they can be overcome. (Interview Thursday, March $23^{\text {th }}$, 2017).

The core implementation of education in schools is teaching and learning activities, the success of teaching and learning activities determine the success of teachers and schools in implementing education. To achieve the success of learning in this case Integrated Social Studies learning, teachers are required to have readiness in preparing lesson planning and manage the implementation of good teaching and learning interaction. From the results of research conducted on teachers in the field of study teaching Integrated Social Studiesthat in general the readiness of teachers in the field of teaching Integrated Social Studiesin SMP Negeri 3 Kuningan included in the category of ready $(79.85 \%)$.

From the results of research conducted on teachers in the field of teaching Integrated Social Studies at SMP Negeri 3 Kuningan in the results of questionnaires the level of teacher readiness in the field of teaching Integrated Social Studiesin terms of preparation of learning plans are included in either category $(78.25 \%)$, this also in line with the results of observation assessment of the lesson plan has been included in the category of very good $(93.85 \%)$ means that in general teachers of the field teaching Integrated Social Studieshas been able to describe the goal / competence of learning according to Kurtilas Integrated Social Studies well, able to choose and determine Integrated Social Studiesmaterials, able to organize the material well, able to determine the method of learning, able to determine the source / media learning, able to develop assessment tools and assessment techniques and able to allocate time well. Implementation of the interaction of teaching and learning in a questionnaire result 


\section{Pupu Saeful Rahmat}

Investigating teachers' readiness in teaching integrated social studies: Indonesian cases

has been included in good category ( $85.95 \%)$, it means that in general the teachers of Integrated Social Studiesteaching subject have been able to open the lesson well, able to present the material well, able to use media, able using props, using communicative subjects during the teaching and learning process, able to motivate students well, organize activities well, able to interact with students communicatively well, able to conclude learning and provide good feedback and able to carry out assessment and use the time with good. But unlike the observation of the implementation of learning is still in sufficient category $(67.50 \%)$.

This difference is caused because one of the indicators in the implementation of teaching and learning interaction that is using media is not fulfilled by the teacher and this is also reflected from one of the questionnaire on learning media indicator that is in the category less (50\%). Yet as Hamalik (1986) in Arsyad (2007) argues that the use of learning media in teaching and learning can generate new desires and interests, generate motivation and stimulate learning activities and bring psychological influences on students.

Through interviews with some teachers of Integrated Social Studies, it can be seen that teachers in the delivery of material that is not the same as the educational background has not been fully mastered. This is caused by several factors, such as the understanding of the material that has not been fully embedded such as educational background, limited funds, lack of training, limited facilities and infrastructure as well as integrated consolidated Social Studiesconcept that has not integrated integrally. In practice the Integrated Social Studies should integrate the learning of geography, economics, history and sociology but to separate the discussion in the chapters discussed. There remains a classification of geography chapters, economic chapters or historical chapters as well as sociology which actually indicates the incompatibility of Integrated Social Studies learning. Integrated Social Studies curriculum deserves a re-revision in its compilation. This can only be resolved if the government, especially the education office, reviews the implementation of this Integrated Social Studies

From the results of the research found that the interview result did not show comprehensively the result of the questionnaire. There is a difference between the two. In a questionnaire, teachers have been readiness in teaching Integrated Social Studies However, in interviews can be found some of the difficulties faced by teachers, especially in the mastery of the material. This is due to the questionnaire filling that is done based on the feeling of the research object so that the result tends to be good. In the interview, more open so that the researcher can find that the teacher of the subject teaching Integrated Social Studiesactually experience constraints in delivering Integrated Social Studies material that is not the same as the educational background, plus the limitations of Integrated Social Studies learning support tools that can hamper the teaching and learning process that ultimately will reduce the maximization of Kurtilas implementation especially in this Integrated Social Studies Therefore,

Depdikbud and schools as institutions that oversee education need to routinely conduct training for teachers of study areas that teach Integrated Social Studies so that they can improve their professional competence.

\section{CONCLUSION}

Based on the discussion of research results, it can be concluded that in general, the readiness of teachers in the field of teaching Integrated Social Studies in SMP Negeri 3 Kuningan viewed from the management of learning included in the ready category. Obstacles faced by teachers in the field of study in teaching Integrated Social Studies is less united geography, economic, historical and sociological concepts in the minds of teachers, and the limitations of instructional means of learning Integrated Social Studiesat at school. However, teachers and prospective teachers to continuously improve their professional competence in Integrated Social 
Indonesian Journal of Learning and Instruction Volume 1, Issue 1, April 2018

Studies to support the implementation of Kurtilas on Integrated Social Studies learning. The school can also improve the procurement of infrastructure and supporting facilities of Integrated Social Studies learning. The government is also expected to regularly conduct training for teachers of the field teaching Integrated Social Studies to keep improving their professional competence.

\section{REFERENCES}

Abror, A. R. (2012). Psikologi pendidikan. Yogyakarta: PT Tiara Wacana.

Davis, G. A. ( 2012 ). Anak berbakat dan pendidikan keberbakatan. Jakarta: PT Indeks, Jakarta.

Djamarah, S. B. (2010). Psikologi belajar. Jakarta: Rineka Cipta.

Kunandar. (2008). Guru profesional implementasi kurikulum tingkat satuan pendidikan (KTSP) dan
p-ISSN 2614-8250, e-ISSN 2614-5677

https://journal.uniku.ac.id/index.php/IJLI

sukses dalam sertifikasi guru. Jakarta: Raja Grafindo Persada.

Majid, A. (2009). Perencanaan pembelajaran mengembangkan standar kompetensi guru. Bandung: Remaja Rosdakarya.

Ollila, J. (2017). Social studies in curriculum integration in elementary classroom: A case study on a Pennsylvania rural school. Journal of Social Studies.

Rahmat, P. S. (2017) Perkembangan peserta didik. Jakarta: PT. Bumi Aksara.

Risang, M. (2012). Kiat sukses menjadi guru PAUD yang disukai anak-anak. Yogyakarta: Araska.

Sugiyono. (2008). Metode penelitian pendidikan pendekatan kuantitatif, kualitatif dan $R \& D$. Bandung: Alfabeta.

Suprijono, A. (2012). Cooperative learning: Teori \& aplikasi PAIKEM. Yogyakarta: Pustaka Pelajar.

Tay, L., \& Diener, E. (2011). Needs and subjective well-being around the world. Journal of Personal Social Psychology, 101(2), 354-365.

Toharuddin, et al. (2011). Membangun literasi sains peserta didik. Bandung: Humaniora. 


\section{Pupu Saeful Rahmat}

Investigating teachers' readiness in teaching integrated social studies: Indonesian cases 